\title{
Breast cancer screening: evidence of benefit depends on the method used
}

\author{
Philippe Autier ${ }^{*}$ and Mathieu Boniol
}

\begin{abstract}
In this article, we discuss the most common epidemiological methods used for evaluating the ability of mammography screening to decrease the risk of breast cancer death in general populations (effectiveness). Case-control studies usually find substantial effectiveness. However when breast cancer mortality decreases for reasons unrelated to screening, the case-control design may attribute to screening mortality reductions due to other causes. Studies based on incidence-based mortality have obtained contrasted results compatible with modest to considerable effectiveness, probably because of differences in study design and statistical analysis. In areas where screening has been widespread for a long time, the incidence of advanced breast cancer should be decreasing, which in turn would translate into reduced mortality. However, no or modest declines in the incidence of advanced breast cancer has been observed in these areas. Breast cancer mortality should decrease more rapidly in areas with early introduction of screening than in areas with late introduction of screening. Nonetheless, no difference in breast mortality trends has been observed between areas with early or late screening start. When effectiveness is assessed using incidence-based mortality studies, or the monitoring of advanced cancer incidence, or trends in mortality, the ecological bias is an inherent limitation that is not easy to control. Minimization of this bias requires data over long periods of time, careful selection of populations being compared and availability of data on major confounding factors. If case-control studies seem apparently more adequate for evaluating screening effectiveness, this design has its own limitations and results must be viewed with caution. See related Opinion article: http://www.biomedcentral.com/1741-7015/10/106 and Commentary http://www. biomedcentral.com/1741-7015/10/164
\end{abstract}

Keywords: breast cancer, case-control, effectiveness, epidemiology, incidence, mortality, screening

\section{Background}

Four randomized trials conducted in Sweden from 1977 to 1993 obtained results suggesting $20 \%$ to $30 \%$ reductions in breast cancer mortality associated with the regular participation of women 40 to 74 years of age in mammography screening [1-4]. These trials encouraged the implementation of mammography screening services and, in 2012, screening programs have been in place for 20 years or more in several high income countries.

Breast screening mobilizes considerable resources and can generate harm due to false positive examinations, overdiagnosis and overtreatment, the amount of which depends on factors such as screening intensity, screening ages, radiologist experience and the legal environment

\footnotetext{
* Correspondence: Philippe.autier@i-pri.org
International Prevention Research Institute, 95 Cours Lafayette, F-69006 Lyon,

* Correspondence: Philippe.autier@i-pri.org
International Prevention Research Institute, 95 Cours Lafayette, F-69006 Lyon, France
}

(c) 2012 Autier and Boniol; licensee BioMed Central Ltd. This is an Open Access article distributed under the terms of the Creative

(for example, defensive medicine in the US) [5-9]. An essential question is thus the effectiveness of screening activities, that is, are mortality reductions observed in the ideal conditions of randomized trials (efficacy) also found in the real world conditions of general population mass screening (effectiveness)?

In their paper, Puliti and Zappa [10] posit that casecontrol studies and studies based on incidence-based mortality (IBM) constitute valid, unbiased evaluations of screening effectiveness. By contrast, studies based on mortality statistics have limitations that explain why their findings are different from those of case-control and IBM studies. As a result of these considerations, the paper proposes to institute the case-control design as the standard method for evaluating breast screening effectiveness. 
In this opinion article, we briefly review the main methods that have been used for evaluating the effectiveness of breast screening and discuss their strengths and weaknesses. Contrary to the opinion of Puliti and Zappa, we suggest that the case-control study design should not be used as the principal method to evaluate the effectiveness of screening programs.

\section{The case-control design}

The case-control design compares the exposure to screening of women who died from breast cancer (the cases) to that of women alive and still at risk of dying from breast cancer at the time of death of the case (the controls). This comparison is deemed to inform on the ability of regular participation in screening to reduce the risk of dying from breast cancer. This design is appealing because of its low cost and swift execution [11].

The limitations of case-control designs for the evaluation of screening effectiveness have been described [12]. However, case-control studies done after 2000 were performed in populations where organized screening programs are established. These programs run databases collecting all of the screening information of women living in a country, including dates of invitation, participation, screening result and follow-up that can be matched with population-based cancer and cause of death registries. Selecting and matching cases and controls from such databases were deemed to guarantee equal opportunity of exposure to screening of both cases and of controls and to allow clear distinction between screening and diagnostic mammography [13].

Despite these improvements, a major problem that arises if the case-control study is conducted within the context of a population screening program is that women who do not participate in screening generally have a poorer outcome [14-17] for reasons that are not related to screening, thus inducing an observed lesser exposure to screening among the cases [18]. A growing number of data documents that, compared with women participating in screening mammography, non-participating women have characteristics associated with a higher risk of dying from breast cancer, such as higher rates of obesity and lower compliance to treatments, and the influence of these characteristics on the risk of breast cancer death exists in the absence of screening [19-21]. So, although a number of non-participants die from breast cancer for reasons unrelated to screening, results of case-control studies may suggest that these deaths are due to not having been screened. This bias in results has been termed the 'selfselection bias'. As the International Agency for Research on Cancer (IARC) Handbook on Breast Cancer Screening concluded, 'Observational studies of screening, such as cohort and case-control studies, may give biased measures of effect because of self-selection of women for screening. There are no certain ways of eliminating the bias' [22].

In 2002, Duffy et al. proposed a method to correct self-selection [18]. This method is based on computation of a quantity 'Dr' that is the ratio of the breast cancer mortality rate in non-participating women at the end of a screening period to the rate in women not invited to screening; that is, the rate in the control group of randomized trials on breast screening or the rate in an area before screening introduction. The quantity $\mathrm{Dr}$ is likely to vary among populations where screening efficiency is evaluated, because proportions of non-participants are variable. Dr is expected to be closer to zero when participation is low, because non-participants would be less atypical of the general population [18].

Table 1 summarizes the effects of correcting for selfselection in a population where breast screening is introduced. As said before, women not likely to participate in screening have a higher risk of breast cancer death that is independent of the existence of screening. Thus, before screening starts, the risk of breast cancer death of women likely to participate in screening is known to be $30 \%$ to $60 \%$ lower than that of women unlikely to participate [16-18]. For our example, we opted for a relative risk of breast cancer death of 0.60 , meaning that before screening starts, the risk of death in participants was $40 \%$ lower than that in non-participants. The scenario in Panel A assumes no effect of screening on breast cancer mortality. A case-control study after a period of screening will find a crude risk of death of 0.61 in participants versus non-participants, but the correction for self-selection will yield an adjusted relative risk of 1.00, in agreement with no screening effectiveness. In Panel B, a 20\% mortality reduction is obtained thanks to screening, and the correction leads to the right estimation of screening effectiveness. Panels C and D are similar to Panels A and B, but during the screening period, a $25 \%$ reduction change in mortality occurs that is unrelated to screening (for example, because of improved treatment). The Dr quantities are smaller because improved treatments have reduced the risk of breast cancer death in non-participants. As a consequence, the corrected relative risk in Panel $\mathrm{C}$ suggests that participation in screening is associated with a $44 \%$ (that is, $100 \times(1.00-0.66))$ reduction in breast cancer mortality, when in reality screening had no impact. The relative risk in Panel D is compatible with true screening effectiveness but the estimated mortality reduction of $52 \%$ (that is, $100 \times(1.00-0.48)$ ) is much larger than the $20 \%$ reduction actually due to screening.

In areas where all women are regularly invited for screening, if breast cancer mortality changes for reasons other than screening, observational studies can hardly avoid the type of bias illustrated in Table 1. One could 
Table 1 Relative risk of breast cancer death before screening start in women likely and not likely to participate in screening, and relative risk of breast cancer death after a period of screening with $75 \%$ participation.

\begin{tabular}{|c|c|c|c|c|c|c|c|c|c|}
\hline & & \multirow{2}{*}{$\begin{array}{c}\begin{array}{c}\text { Before } \\
\text { screening }\end{array} \\
\begin{array}{c}\text { BC death } \\
\text { rate }^{\mathrm{a}}\end{array}\end{array}$} & \multicolumn{3}{|c|}{ After years of screening } & \multicolumn{4}{|c|}{ Correction according to Duffy et al. (2002) [18] } \\
\hline & & & $\begin{array}{l}\text { Change in mortality due } \\
\text { to screening }\end{array}$ & $\begin{array}{l}\text { Change in mortality unrelated } \\
\text { to screening }\end{array}$ & $\begin{array}{l}\text { BC death } \\
\text { rate }^{\mathrm{a}}\end{array}$ & $\mathrm{Dr}$ & $\begin{aligned} A= & p \times R R \\
& \times \mathrm{Dr}\end{aligned}$ & $\begin{aligned} B= & 1-[(1-p) \\
& \times \mathrm{Dr}]\end{aligned}$ & $\begin{array}{c}\text { Corrected RR } \\
(=\mathrm{A} / \mathrm{B})\end{array}$ \\
\hline \multirow{4}{*}{$\begin{array}{l}\text { Panel } \\
\text { A }\end{array}$} & Participants & 86 & $0 \%$ & $0 \%$ & 86 & & & & \\
\hline & Non-participants & 142 & $0 \%$ & $0 \%$ & 142 & & & & \\
\hline & All women ${ }^{b}$ & 100 & $0 \%$ & $0 \%$ & 100 & & & & \\
\hline & $\begin{array}{l}\text { RR breast cancer death, participants } \\
\text { versus non-participants }\end{array}$ & 0.61 & & & 0.61 & 1.42 & 0.65 & 0.65 & 1.00 \\
\hline \multirow{4}{*}{$\begin{array}{l}\text { Panel } \\
\text { B }\end{array}$} & Participants & 86 & $-20 \%$ & $0 \%$ & 69 & & & & \\
\hline & Non-participants & 142 & $0 \%$ & $0 \%$ & 142 & & & & \\
\hline & All women ${ }^{b}$ & 100 & $-15 \%$ & $0 \%$ & 85 & & & & \\
\hline & $\begin{array}{l}\text { RR breast cancer death, participants } \\
\text { versus non-participants }\end{array}$ & 0.61 & & & 0.48 & 1.42 & 0.52 & 0.65 & 0.80 \\
\hline \multirow{4}{*}{$\begin{array}{l}\text { Panel } \\
\text { C }\end{array}$} & Participants & 86 & $0 \%$ & $-25 \%$ & 65 & & & & \\
\hline & Non-participants & 142 & $0 \%$ & $-25 \%$ & 107 & & & & \\
\hline & All women ${ }^{b}$ & 100 & $0 \%$ & $-25 \%$ & 75 & & & & \\
\hline & $\begin{array}{l}\text { RR breast cancer death, participants } \\
\text { versus non-participants }\end{array}$ & 0.61 & & & 0.61 & 1.07 & 0.48 & 0.73 & 0.66 \\
\hline \multirow{4}{*}{$\begin{array}{l}\text { Panel } \\
\text { D }\end{array}$} & Participants & 86 & $-20 \%$ & $-25 \%$ & 47 & & & & \\
\hline & Non-participants & 142 & $0 \%$ & $-25 \%$ & 107 & & & & \\
\hline & All women ${ }^{b}$ & 100 & $-15 \%$ & $-25 \%$ & 60 & & & & \\
\hline & $\begin{array}{l}\text { RR breast cancer death, participants } \\
\text { versus non-participants }\end{array}$ & 0.61 & & & 0.44 & 1.07 & 0.35 & 0.73 & 0.48 \\
\hline
\end{tabular}


rely on breast cancer mortality rates in women of not (yet) invited women. However, breast cancer survival varies from region to region [23], and therefore, it is uncertain whether rates observed in uninvited women are valid for computing the quantity Dr. To be reliable, the quantity Dr needs to be assessed for each study, and should take into account changes in mortality due to factors other than screening in both unscreened and in uninvited women.

\section{Incidence-based mortality studies}

Incidence based mortality (IBM) studies compare breast cancer mortality in patients with breast cancer diagnosed during similar periods before (pre-screening period) and after (screening period) screening introduction. Both breast cancer diagnosis and death must occur during the pre-screening or during the screening period. The advantage of this method is that it uses the 'refined mortality' that is obtained by excluding breast cancer deaths due to cancers diagnosed before start of the pre-screening period or before start of the screening period. IBM studies are challenging as they require first the possibility to link cancer registries to cause of death registries and second, to assemble the exact data on women who had breast cancer and died from it during the pre-screening and during the screening period.

According to the IARC Handbook on Breast Cancer Screening [22], 'Refined mortality should be estimated for screened and unscreened population to ensure comparability. Furthermore, cancer registration with data on treatment is likely to be the only means for differentiating the confounding effect of changes in treatment from the effect of screening.' Data on treatment is essential because variations in breast cancer mortality changes between regions may be due to differences in patient management rather than to screening, and a number of studies have documented substantial variability in patient management across regions, including in Sweden [23-26].

IBM studies on breast cancer screening [27-34] are summarized in Table 2 . No study had data on patient management in pre-screening and in screening periods and thus no study could control for variations in patient management between areas. In all IBM studies, individual exposure to screening was generally known only for women diagnosed with breast cancer, but not for other women. Therefore, denominators (that is, person-years of exposure or non-exposure to screening) were estimated at population level, and not at individual level. In this respect, IBM studies needs to be considered as ecological studies.

An IBM study in Finland based on data from the Finish Cancer Registry found an $11 \%$ mortality reduction [31]. All four Swedish IBM studies obtained results indicating considerable screening effectiveness $[27,29,30,32]$. However, in Sweden, breast cancer mortality has steadily decreased by $0.9 \%$ per year since 1972 , well before screening started $[35,36]$. Because they had no comparison areas where no screening existed during the entire study period, two IBM studies done in Sweden [27,29] could not realize how these secular trends influenced their results.

Swedish IBM studies corrected their results in various ways (Table 2). Two studies corrected changes in breast cancer mortality for changes in breast cancer incidence $[27,29]$. This correction is based on the assumption that if screening had not existed, trends in breast cancer mortality would have paralleled incidence trends. This correction is not justified because first, in the absence of screening, mortality and incidence trends are not correlated. Second, mammography screening itself is the main cause of increasing breast cancer incidence. The correction for lead time is also questionable, as lead time is known to affect survival statistics but not mortality [37].

Three IBM studies, one in Denmark [28] and two in Norway [33,34], included comparison areas as well as historical areas (that is, the screening and comparison areas before screening start) where women were not invited to screening (Table 2). The two studies in Norway were based on the same screening areas but used different comparison areas. The study in Denmark found a statistically significant $25 \%$ mortality reduction associated with screening, while the two studies in Norway found $10 \%$ and $7 \%$ reductions that were not statistically significant.

Despite comparable design, IBM studies in Denmark and in Norway differed in several ways (Tables 2 and 3). In Denmark, screening was mainly performed in Copenhagen, the capital city. The data source for breast cancer cases was the Copenhagen mammography screening register, whereas for the rest of the country, a comparison group was constructed from the central population register that was linked to the Danish Cancer Registry. In Norway, screening was initiated in four counties; in both studies, the data source for breast cancer cases was the Norwegian Cancer Registry. In Denmark, in the pre-screening period, the mortality rate of Copenhagen women was $33 \%$ higher (that is, 69 compared with 52) than among women living elsewhere in Denmark (Table 3). Also, in comparison areas, from the pre-screening to the screening period, no decline in mortality rates occurred. Such contrast between the screened and comparison areas did not exist in the Norwegian studies. It is probable that the results of the Danish study were owing to differences in ways by which breast cancer cases were assembled in screened and in comparison areas.

A final point is that IBM studies could underestimate mortality reductions if substantial mammography screening is already present in comparison areas. Detailed information on the provision of mammography examinations in Sweden and Norway indicated that mammography 
Table 2 Summary of main incidence-based mortality studies on breast cancer screening.

\begin{tabular}{|c|c|c|c|c|c|c|c|c|c|c|}
\hline \multirow[t]{2}{*}{ Study } & \multirow[t]{2}{*}{ Country } & \multirow[t]{2}{*}{ Areas in study } & \multirow{2}{*}{$\begin{array}{l}\text { Age of } \\
\text { screened } \\
\text { women }\end{array}$} & \multirow{2}{*}{$\begin{array}{l}\text { Data on } \\
\text { treatments } \\
\text { in screening } \\
\text { and non- } \\
\text { screening } \\
\text { areas }\end{array}$} & \multirow{2}{*}{$\begin{array}{l}\text { Comparison areas } \\
\text { where no } \\
\text { screening existed } \\
\text { during the entire } \\
\text { screening period }\end{array}$} & \multirow{2}{*}{$\begin{array}{l}\text { Historical } \\
\text { comparison } \\
\text { areas }^{\mathrm{a}}\end{array}$} & \multirow{2}{*}{$\begin{array}{l}\text { Effect of } \\
\text { screening } \\
\text { on the } \\
\text { risk of BC } \\
\text { death }\end{array}$} & \multicolumn{3}{|c|}{ Adjustment of results for: } \\
\hline & & & & & & & & $\begin{array}{c}\text { Self- } \\
\text { selection }\end{array}$ & Incidence & $\begin{array}{l}\text { Lead } \\
\text { time }\end{array}$ \\
\hline $\begin{array}{l}\text { Tabár et } \\
\text { al. } 2003 \\
{[27]}\end{array}$ & Sweden & $\begin{array}{c}\text { Dalarna and } \\
\text { Kopparberg } \\
\text { counties }\end{array}$ & 40 to 69 & No & No & No & $-45 \%$ & Yes & Yes & No \\
\hline $\begin{array}{l}\text { Olsen et } \\
\text { al. } 2005 \\
{[28]}\end{array}$ & Denmark & $\begin{array}{l}\text { Copenhagen } \\
\text { where screening } \\
\text { took place } \\
\text { compared to the } \\
\text { rest of the } \\
\text { country }\end{array}$ & 50 to 69 & No & Yes & Yes & $-25 \%$ & No & No & No \\
\hline $\begin{array}{l}\text { SOSSEG } \\
2006[29]\end{array}$ & Sweden & $\begin{array}{c}\text { About half of } \\
\text { Swedish counties }\end{array}$ & $\begin{array}{l}40(50) \text { to } \\
69(74)\end{array}$ & $\begin{array}{l}\text { Yes, but only } \\
\text { in non- } \\
\text { participants }\end{array}$ & No & No & $-27 \%$ & Yes & Yes & No \\
\hline $\begin{array}{l}\text { Jonsson } \\
2007[30]\end{array}$ & Sweden & $\begin{array}{l}\text { Four Swedish } \\
\text { counties }\end{array}$ & 40 to 74 & No & Yes & No & $-26 \%$ & Yes & No & Yes \\
\hline $\begin{array}{l}\text { Anttila et } \\
\text { al. } 2008 \\
\text { [31] }\end{array}$ & Finland & All the country & 50 to 69 & No & No & No & $-11 \%$ & No & No & No \\
\hline $\begin{array}{l}\text { Hellquist } \\
\text { et al. } \\
2010 \text { [32] }\end{array}$ & Sweden & $\begin{array}{l}\text { All Swedish } \\
\text { counties }\end{array}$ & 40 to 49 & No & Yes & No & $-26 \%$ & Yes & No & Yes \\
\hline $\begin{array}{l}\text { Kalager } \\
\text { et al. } \\
2010 \text { [33] }\end{array}$ & Norway & $\begin{array}{l}\text { Four counties } \\
\text { with pilot } \\
\text { program plus } \\
\text { comparison } \\
\text { counties }\end{array}$ & 50 to 69 & No & Yes & Yes & $-10 \%(N S)$ & No & No & No \\
\hline $\begin{array}{l}\text { Olsen et } \\
\text { al. } 2012 \\
{[34]}\end{array}$ & Norway & $\begin{array}{l}\text { Four counties } \\
\text { with pilot } \\
\text { program plus } \\
\text { comparison } \\
\text { counties }\end{array}$ & 50 to 69 & No & Yes & Yes & -7 (NS) & No & No & No \\
\hline
\end{tabular}

BC: breast cancer; NS: statistically non-significant. ${ }^{a}$ Data on breast cancer death rates in historical comparison groups, that is, in screening areas and in comparison areas before screening started in screening areas.

screening outside the national breast screening programs was uncommon [38-40].

\section{Change in the incidence of advanced breast cancer}

Clinical data show a strong correlation between the size of breast cancer and the likelihood of metastases in axillary lymph nodes or in distant organs. Breast cancer screening is based on the principle that detection of a cancer when still small and not symptomatic prevents progression to advanced disease associated with positive lymph nodes or distant metastases. The consequence of early detection would be a reduction of the risk of death from breast cancer.

Monitoring the incidence of advanced cancer thus corresponds to the way screening works. In addition, the incidence of advanced breast cancer is not influenced by subsequent treatments. Therefore, in populations where breast screening has been widespread for a long period of time (say, seven years or more), a reduction of advanced cancer incidence should reflect the impact of screening activities alone. Longstanding broad consensus exists for considering a decrease in advanced breast cancer incidence as the best early indicator of the impact of screening $[1,22,41-43]$. This consensus was in agreement with cancer registry data showing marked decreases in the incidence of advanced cervical and colorectal cancers over the last decades $[44,45]$, which illustrated the contribution of screening to the reductions in mortality from these two cancers. Of note, decreases in the incidence of advanced breast cancer after screening introduction should not be confused with decreases in proportions of advanced breast cancer [22]. The latter does not necessarily reflect the influence of screening because screening will increase numbers of early cancers detected, due to lead time (advance in diagnosis) and to length time (overdiagnosis). Increases in the number of 
Table 3 Incidence-based mortality studies for the evaluation of mammography screening effectiveness in Denmark and in Norway.

\begin{tabular}{|c|c|c|c|c|c|c|c|}
\hline & $\begin{array}{c}\text { Years } \\
\text { included } \\
\text { in study }\end{array}$ & $\begin{array}{c}\text { Year of } \\
\text { screening } \\
\text { introduction in } \\
\text { screening areas }\end{array}$ & $\begin{array}{c}\text { Age } \\
\text { groups }\end{array}$ & $\begin{array}{l}\text { BC mortality rate in } \\
\text { the pre-screening } \\
\text { period (historical } \\
\text { control) }\end{array}$ & $\begin{array}{l}\text { BC mortality } \\
\text { rate in the } \\
\text { screening } \\
\text { period }\end{array}$ & $\begin{array}{l}\text { Ratio of BC mortality } \\
\text { rates, screening versus } \\
\text { pre-screening period }^{\mathrm{a}}\end{array}$ & $\begin{array}{c}\text { Ratio of } \mathrm{BC} \text { mortality } \\
\text { rates, screening } \\
\text { versus non-screening } \\
\text { areas }^{\mathrm{a}}\end{array}$ \\
\hline $\begin{array}{l}\text { Screening } \\
\text { areas }\end{array}$ & & & & No screening & Screening & & \\
\hline $\begin{array}{l}\text { Denmark, } \\
\text { Olsen et al. } \\
2005 \text { [28] }\end{array}$ & $\begin{array}{l}1981 \text { to } \\
2001\end{array}$ & 1991 & $\begin{array}{l}50 \text { to } \\
79\end{array}$ & 69 & 52 & 0.75 & 0.74 \\
\hline $\begin{array}{l}\text { Norway, } \\
\text { Kalager et al. } \\
2010 \text { [33] }\end{array}$ & $\begin{array}{l}1986 \text { to } \\
2005\end{array}$ & 1996 & $\begin{array}{l}50 \text { to } \\
84\end{array}$ & 33 & 24 & 0.73 & 0.9 \\
\hline $\begin{array}{l}\text { Norway, } \\
\text { Olsen et al. } \\
2012 \text { [34] }\end{array}$ & $\begin{array}{l}1990 \text { to } \\
2008\end{array}$ & 1996 & $\begin{array}{l}50 \text { to } \\
84\end{array}$ & 35 & 27 & 0.77 & 0.91 \\
\hline $\begin{array}{l}\text { Comparison } \\
\text { (non- } \\
\text { screening) } \\
\text { areas }\end{array}$ & & & & No screening & No screening & & \\
\hline $\begin{array}{l}\text { Denmark, } \\
\text { Olsen et al. } \\
2005 \text { [28] }\end{array}$ & $\begin{array}{l}1981 \text { to } \\
2001\end{array}$ & - & $\begin{array}{l}50 \text { to } \\
79\end{array}$ & 52 & 53 & 1.02 & reference \\
\hline $\begin{array}{l}\text { Norway, } \\
\text { Kalager et al. } \\
2010 \text { [33] }\end{array}$ & $\begin{array}{l}1986 \text { to } \\
2005\end{array}$ & - & $\begin{array}{l}50 \text { to } \\
84\end{array}$ & 31 & 25 & 0.81 & reference \\
\hline $\begin{array}{l}\text { Norway, } \\
\text { Olsen et al. } \\
2012 \text { [34] }\end{array}$ & $\begin{array}{l}1990 \text { to } \\
2008\end{array}$ & - & $\begin{array}{l}50 \text { to } \\
84\end{array}$ & 39 & 33 & 0.85 & reference \\
\hline
\end{tabular}

Figures in the table are breast cancer mortality rates per 100,000 women ages 50 to 79 in Denmark and 50 to 84 in Norway. ${ }^{a}$ Rate ratios may slightly differ from those of the original publications reported in Table 2 due to rounding and absence of statistical modelling. BC: breast cancer; NR: not reported.

early cancer arithmetically lead to increases in proportions of early cancer that in turn lead to decreases in proportions of advanced cancer. Therefore, published data show that proportions of advanced cancer usually diminishes in years following breast screening introduction while concomitant reductions in the incidence rate of advanced cancer may be modest or absent.

The IARC meeting of 2002 devoted a section on trends in advanced breast cancer incidence [22]. However, at that time, few cancer registries had collected adequate data over a too short period after screening introduction.

From 2006 onwards, with accumulating years of screening activities in populations where good quality cancer registries exist, larger amounts of data on advanced breast cancer incidence were available. A systematic review showed that, in areas in Europe, North America and Australia where screening has been widespread for a long time, no or small decreases in the incidence of advanced and very advanced breast cancer was observed [46]. An analysis of breast cancer incidence in the US reached the same conclusion [47]. A team of radiologists performed an in-depth analysis of screen-detected, interval and all breast cancers diagnosed from 1989 to 2007 in the south-east region of the Netherlands and found no decline in the incidence of advanced breast cancer [48]. In the UK, cancer registry data for Scotland, Northern Ireland and the West Midlands showed no decline in the incidence of advanced breast cancer after the introduction of screening in 1989 [46,49]. In Norway, the study that found a modest non-significant reduction in the risk of breast cancer death in screened versus non-screened populations [33] also found no difference in rates of advanced breast cancer in these populations [39].

A question is whether the incidence of advanced breast cancer would have increased in the absence of screening. Few data indicate that in areas where screening has been widespread for some time, the answer is likely to be negative. In the Netherlands, where screening before 50 and above 69 years of age was rare, there were no time changes in the incidence of advanced breast cancer in women younger than 50 and older than 69 years of age [42,50]. In Victoria (Australia), the trends in the incidence of advanced breast cancer in non-attending women were similar to that observed among screened women [51].

\section{Changes in breast cancer mortality rates in areas with} large difference in the timing of screening introduction If breast screening was capable of reducing breast cancer mortality by $20 \%$ to $30 \%$ after seven to ten years, 
reductions should be quicker and more apparent in countries with early screening implementation whereas delayed and smaller reductions should be observed in countries with late implementation.

The ecological design may be useful for comparative effectiveness research, that is, comparison of diseasespecific trends in countries with similar quality of health systems and access to treatment, but with different prevention policies. This design has been used when randomized trials were unfeasible, for example the banning of smoking in public places in 2006 in Scotland was followed by a one-year $17 \%$ reduction in hospital admissions for acute myocardial events [52]. By contrast, in England where such a ban did not yet exist, the hospital admission during that one-year period decreased by $4 \%$ [52]. In this respect, the IARC Handbook on Breast Cancer Screening stated that, 'Routine screening programmes can be evaluated most readily by time trends and differential mortality from the disease for which screening is being performed. Probably the best known is screening for cervical cancer. The substantial differences among the Nordic countries in the extent of organized screening were closely matched by the mortality rates from cervical cancer (Läärä et al., 1987)' [22].

Another study mimicked the Nordic study on cervical cancer screening [53] by selecting three pairs of European countries (the Netherlands and Belgium; Northern Ireland and Ireland; Sweden and Norway) with similar prevalence of risk factors for breast cancer death, access to treatment and expenditures for health, but where by year 1993, nationwide screening was in place in the first country of each pair, but implemented 10 to 12 years later in the second country [54]. In each country pair, breast cancer mortality rates in 1987 to 1989 were comparable and from 1989 to 2007, equivalent declines in breast cancer mortality occurred. These results agreed with the observation that breast cancer mortality reductions in high income countries are unrelated to the temporal introduction of screening mammography $[35,55]$.

Perhaps a longer period would be needed to observe the benefits of screening. However, in the Netherlands and the UK, changes in mortality observed six to ten years after screening introduction were attributed to screening $[56,57]$. In this respect, the 18 -year-long period used in country pairs [54] was long enough to observe the impact of screening on mortality. Another limitation is the contamination of mortality data during the screening era with deaths due to breast cancer diagnosed before screening start. In 1993, the eight-year survival of deadly (stage III) breast cancer was about 30\% [58]. The study on country pairs [54] extended over 15 to 19 years after screening start. Hence most fatal breast cancers diagnosed before the screening era weighted little in the breast cancer mortality burden after 2000 .
Two other studies on long-term breast cancer mortality trends according to timing of screening introduction were conducted in Danish regions and in Swedish counties [36,59]. During the 15 years following screening start, no change in the difference in mortality trends was noticeable between the screened and unscreened Danish regions. In Swedish counties, mortality rates continued to follow the monotonous downward trends that started in 1972, without sign that screening may have influenced these trends.

\section{Conclusions}

Case-control studies are relatively easy and quick to perform. However, when cancer mortality is decreasing for reasons unrelated to screening, this design may not be able to control the self-selection bias, therefore deaths prevented through other interventions may be attributed to screening. In this respect, contrary to the suggestion of Puliti and Zappa [10], a case-control study should not be considered as the standard method for the evaluation of breast screening effectiveness.

IBM studies focus on deaths from breast cancer occurring during periods of the same duration before and after screening introduction. But results from IBM studies seem to vary according to the design adopted and adjustments performed during the statistical analysis. Also, results may be biased if secular trends in mortality, improved treatment and geographical variations in patient management are not considered.

The method based on incidence trends of advanced breast cancer corresponds to the primary goal of screening that consists in preventing advanced cancer. Its main limitation is the paucity of population-based cancer registries that have collected data on breast cancer characteristics over long periods of time. Monitoring incidence trends in women living in areas with screening but not invited to screening is desirable for verifying that the lack of decreasing trends in advanced cancer is not due to the increasing prevalence of factors associated with greater risk of advanced breast cancer.

A comparison of mortality trends between screened and unscreened areas takes into consideration factors influencing mortality in the areas being compared, but several methodological requirements need to be met for minimizing ecological biases, such as a period of observation that is long enough, availability of data on participation in screening during the observation period, and availability of data on major confounding factors like access to treatment.

Studies based on time trends of advanced disease incidence and cancer-specific mortality, with use of designs enabling comparisons between periods and geographical areas, have documented that screening for cervical and colorectal cancer contributed to decreasing mortality from these two cancers $[44,45,53]$. We thus conclude 
that, similarly, an evaluation of the effectiveness of breast screening should be based on monitoring of advanced cancer incidence, as well as on mortality trends in areas with contrasting screening policies where good information is available on non-screening factors involved in mortality, so that ecological biases can be minimized. Indeed, it remains to be explained why results from these two types of studies on breast screening effectiveness do not match the results of Swedish randomized trials.

\section{Authors' contributions}

PA drafted the article, PA and MB summarized published data and formulated the statistical example, PA and MB discussed the content. Both authors approved the final version of the manuscript.

\section{Competing interests}

The authors declare that they have no competing interests.

Received: 24 February 2012 Accepted: 12 December 2012 Published: 12 December 2012

\section{References}

1. Tabár L, Fagerberg CJ, Gad A, Baldetorp L, Holmberg LH, Gröntoft O, Ljungquist U, Lundström B, Månson JC, Eklund G, Day NE, Pettersson F: Reduction in mortality from breast cancer after mass screening with mammography. Randomised trial from the Breast Cancer Screening Working Group of the Swedish National Board of Health and Welfare. Lancet 1985, 1:829-832.

2. Andersson I, Aspegren $K$, Janzon L, Landberg $T$, Lindholm $K$, Linell $F$, Ljungberg O, Ranstam J, Sigfússon B: Mammographic screening and mortality from breast cancer: the Malmo mammographic screening trial. BMJ 1988, 297:943-948.

3. Frisell J, Lidbrink E, Hellström L, Rutqvist LE: Follow-up after 11 years update of mortality results in the Stockholm mammographic screening trial. Breast Cancer Res Treat 1997, 45:263-270.

4. Bjurstam N, Björneld L, Warwick J, Sala E, Duffy SW, Nyström L, Walker N, Cahlin E, Eriksson O, Hafström LO, Lingaas H, Mattsson J, Persson S, Rudenstam CM, Salander H, Säve-Söderbergh J, Wahlin T: The Gothenburg breast screening trial. Cancer 2003, 97:2387-2396.

5. Perry N, Broeders M, de Wolf C, Törnberg S, Holland R, von Karsa L: European guidelines for quality assurance in breast cancer screening and diagnosis. Ann Oncol 2008, 19:614-622.

6. Smith-Bindman R, Chu PW, Miglioretti DL, Sickles EA, Blanks R, BallardBarbash R, Bobo JK, Lee NC, Wallis MG, Patnick J, Kerlikowske K: Comparison of screening mammography in the United States and the United Kingdom. JAMA 2003, 290:2129-2137.

7. Fletcher SW: Breast cancer screening: a 35-year perspective. Epidemiol Rev 2011, 33:165-175.

8. Dick JF, Gallagher TH, Brenner RJ, Yi JP, Reisch LM, Abraham L, Miglioretti DL, Carney PA, Cutter GR, Elmore JG: Predictors of radiologists' perceived risk of malpractice lawsuits in breast imaging. AJR Am J Roentgenol 2009, 192:327-333.

9. Amir E, Bedard PL, Ocana A, Seruga B: Benefits and harms of detecting clinically occult breast cancer. J Nat/ Cancer Inst 2012, 104:1542-1547.

10. Puliti D, Zappa M: Breast cancer screening: are we seeing the benefit? BMC Med 2012, 10:106.

11. Sasco AJ, Day NE, Walter SD: Case-control studies for the evaluation of screening. J Chron Dis 1986, 39:399-405.

12. Cronin KA, Weed DL, Connor RJ, Prorok PC: Case-control studies of cancer screening: theory and practice. J Natl Cancer Inst 1998, 90:498-504.

13. Otto SJ, Fracheboud J, Verbeek AL, Boer R, Reijerink-Verheij JC, Otten JD, Broeders MJ, de Koning HJ, National Evaluation Team for Breast Cancer Screening: Mammography screening and risk of breast cancer death: a population-based case-control study. Cancer Epidemiol Biomarkers Prev 2012, 21:66-73.
14. Duffy SW, Tabár L, Fagerberg G, Gad A, Gröntoft O, South MC, Day NE: Breast screening, prognostic factors and survival - results from the Swedish two county study. Br J Cancer 1991, 64:1133-1138.

15. Aarts MJ, Voogd AC, Duijm LE, Coebergh JW, Louwman WJ: Socioeconomic inequalities in attending the mass screening for breast cancer in the south of the Netherlands-associations with stage at diagnosis and survival. Breast Cancer Res Treat 2011, 128:517-525.

16. Mook S, Van 't Veer $L$, Rutgers EJ, Ravdin PM, van de Velde AO, van Leeuwen FE, Visser O, Schmidt MK: Independent prognostic value of screen detection in invasive breast cancer. J Natl Cancer Inst 2011, 103:585-597.

17. Biesheuvel C, Czene K, Orgeás CC, Hall P: The role of mammography screening attendance and detection mode in predicting breast cancer survival - is there added prognostic value? Cancer Epidemiol 2011, 35:545-550.

18. Duffy SW, Cuzick J, Tabár L, Vitak B, Hsiu-His Chen T, Yen MF, Smith RA: Correcting for non-compliance bias in case-control studies to evaluate cancer screening programmes. Appl Statist 2002, 51(Part 2):235-243.

19. Flamant C, Gauthier E, Clavel-Chapelon F: Determinants of noncompliance to recommendations on breast cancer screening among women participating in the French E3N cohort study. Eur I Cancer Prev 2006, 15:27-33.

20. Ferrante JM, Chen PH, Crabtree BF, Wartenberg D: Cancer screening in women: BMI and adherence to physician recommendations. Am J Prev Med 2007, 32:525-531.

21. La Vecchia C, Giordano SH, Hortobagyi GN, Chabner B: Overweight, obesity, diabetes, and risk of breast cancer: interlocking pieces of the puzzle. Oncologist 2011, 16:726-729.

22. International Agency for Research on Cancer: IARCWHOH Handbooks of Cancer Prevention vol. 7: Breast Cancer Screening Lyon: IARC Press; 2002.

23. Sant M, Minicozzi P, Allemani C, Cirilli C, Federico M, Capocaccia R, Budroni M, Candela P, Crocetti E, Falcini F, Ferretti S, Fusco M, Giacomin A, La Rosa F, Mangone L, Natali M, Leon MP, Traina A, Tumino R, Zambon P: Regional inequalities in cancer care persist in Italy and can influence survival. Cancer Epidemiol 2012, 36:541-547.

24. Wilking U, Jönsson B, Wilking N, Bergh J: Trastuzumab use in breast cancer patients in the six health care regions in Sweden. Acta Oncol 2010, 49:844-850.

25. Ess $\mathrm{S}$, Savidan A, Frick $H$, Rageth Ch, Vlastos $G$, Lütolf U, Thürlimann B: Geographic variation in breast cancer care in Switzerland. Cancer Epidemiol 2010, 34:116-121.

26. Boscoe FP, Johnson CJ, Henry KA, Goldberg DW, Shahabi K, Elkin EB, Ballas LK, Cockburn M: Geographic proximity to treatment for early stage breast cancer and likelihood of mastectomy. Breast 2011, 20:324-328.

27. Tabár L, Yen MF, Vitak B, Chen HH, Smith RA, Duffy SW: Mammography service screening and mortality in breast cancer patients: 20-year followup before and after introduction of screening. Lancet 2003, 361:1405-1410.

28. Olsen AH, Njor SH, Vejborg I, Schwartz W, Dalgaard P, Jensen MB, Tange UB, Blichert-Toft M, Rank F, Mouridsen H, Lynge E: Breast cancer mortality in Copenhagen after introduction of mammography screening: cohort study. BMJ 2005, 330:220

29. Swedish Organised Service Screening Evaluation Group: Reduction in breast cancer mortality from organized service screening with mammography: 1. Further confirmation with extended data. Cancer Epidemiol Biomarkers Prev 2006, 15:45-51.

30. Jonsson $H$, Bordas $P$, Wallin $H$, Nyström L, Lenner P: Service screening with mammography in Northern Sweden: effects on breast cancer mortality an update. J Med Screen 2007, 14:87-93.

31. Anttila A, Sarkeala T, Hakulinen T, Heinävaara S: Impacts of the Finnish service screening programme on breast cancer rates. BMC Public Health 2008, 8:38.

32. Hellquist BN, Duffy SW, Abdsaleh S, Björneld L, Bordás P, Tabár L, Viták B, Zackrisson S, Nyström L, Jonsson H: Effectiveness of population-based service screening with mammography for women ages 40 to 49 years: evaluation of the Swedish Mammography Screening in Young Women (SCRY) cohort. Cancer 2011, 117:714-722.

33. Kalager M, Zelen M, Langmark F, Adami HO: Effect of screening mammography on breast-cancer mortality in Norway. N Engl J Med 2010, 363:1203-1210. 
34. Olsen AH, Lynge E, Njor SH, Kumle M, Waaseth M, Braaten T, Lund E: Breast cancer mortality in Norway after the introduction of mammography screening. Int J Cancer 2013, 132:208-214.

35. Autier P, Boniol M, LaVecchia C, Vatten L, Gavin A, Héry C, Heanue M: Disparities in breast cancer mortality trends between thirty European countries: retrospective trend analysis of WHO mortality database. BMJ 2010, 341:c3620.

36. Autier P, Koechlin A, Smans M, Vatten L, Boniol M: Mammography screening and breast cancer mortality in Sweden. J Natl Cancer Inst 2012, 104:1080-1093.

37. Welch $H G$, Schwartz $L M$, Woloshin S: Are increasing 5-year survival rates evidence of success against cancer? JAMA 2000, 283:2975-2978.

38. Olsson S, Andersson I, Karlberg I, Bjurstam N, Frodis E, Håkansson S: Implementation of service screening with mammography in Sweden: from pilot study to nationwide programme. J Med Screen 2000, 7:14-18.

39. Kalager M, Adami HO, Bretthauer M, Tamimi RM: Overdiagnosis of invasive breast cancer due to mammography screening: results from the Norwegian Screening Program. Ann Intern Med 2012, 156:491-499.

40. Autier P: Mammography screening before introduction of the national breast screening programme in Norway. Int J Cancer 2012, Epub ahead of print.

41. Smith RA, Duffy SW, Gabe R, Tabar L, Yen AMF, Chen THH: The randomized trials of breast cancer screening: what have we learned? Radiol Clin North Am 2004, 42:793-806.

42. Fracheboud J, Otto SJ, van Dijck JA, Broeders MJ, Verbeek AL, de Koning HJ, National Evaluation Team for Breast cancer screening (NETB): Decreased rates of advanced breast cancer due to mammography screening in the Netherlands. Br J Cancer 2004, 91:861-867.

43. Autier P, Héry C, Haukka J, Boniol M, Byrnes G: Advanced breast cancer and breast cancer mortality in randomized controlled trials on mammography screening. J Clin Oncol 2009, 27:5919-5923.

44. Sigurdsson K, Sigvaldason H: Effectiveness of cervical cancer screening in Iceland, 1964-2002: a study on trends in incidence and mortality and the effect of risk factors. Acta Obstet Gynecol Scand 2006, 85:343-349.

45. Edwards BK, Ward E, Kohler BA, Eheman C, Zauber AG, Anderson RN, Jemal A, Schymura MJ, Lansdorp-Vogelaar I, Seeff LC, van Ballegooijen M, Goede $S L$, Ries $L A$ : Annual report to the nation on the status of cancer, 1975-2006, featuring colorectal cancer trends and impact of interventions (risk factors, screening, and treatment) to reduce future rates. Cancer 2010, 116:544-573.

46. Autier P, Boniol M, Middleton R, Doré JF, Héry C, Zheng T, Gavin A: Advanced breast cancer incidence following population-based mammographic screening. Ann Oncol 2011, 22:1726-1735.

47. Esserman $L$, Shieh $Y$, Thompson I: Rethinking screening for breast cancer and prostate cancer. JAMA 2009, 302:1685-1692

48. Nederend J, Duijm LE, Voogd AC, Groenewoud JH, Jansen FH, Louwman MW: Trends in incidence and detection of advanced breast cancer at biennial screening mammography in the Netherlands: a population based study. Breast Cancer Research 2012, 14:R10.

49. Autier $\mathrm{P}$, Boniol M: The incidence of advanced breast cancer in the West Midlands, United Kingdom. Eur J Cancer Prev 2012, 21:217-221.

50. NETB. National Evaluation Team for Breast Cancer Screening: National Evaluation of Breast Cancer Screening in the Netherlands 11th Evaluation Report Rotterdam and Nijmegen: NETB; 2005.

51. Harmer C, Staples M, Kavanagh AM: Evaluation of breast cancer incidence: is the increase due entirely to mammographic screening? Cancer Causes Control 1999, 10:333-337.

52. Pell JP, Haw S, Cobbe S, Newby DE, Pell AC, Fischbacher C, McConnachie A, Pringle S, Murdoch D, Dunn F, Oldroyd K, Macintyre P, O'Rourke B, Borland W: Smoke-free legislation and hospitalizations for acute coronary syndrome. New Engl J Med 2008, 359:482-491.

53. Läärä E, Day NE, Hakama M: Trends in mortality from cervical cancer in the Nordic countries: association with organized screening programmes. Lancet 1987, 1:1247-1249.

54. Autier P, Boniol M, Gavin A, Vatten L: Breast cancer mortality in neighbouring European countries with different levels of screening but similar access to treatment: trend analysis of WHO mortality database. BMJ 2011, 343:d4411.

55. Bleyer A: US breast cancer mortality is consistent with European Data. BMJ 2011, 343:d5630.
56. Otten JD, Broeders MJ, Fracheboud J, Otto SJ, de Koning HJ, Verbeek AL: Impressive time-related influence of the Dutch screening programme on breast cancer incidence and mortality, 1975-2006. Int J Cancer 2008, 123:1929-1934.

57. Blanks RG, Moss SM, McGahan CE, Quinn MJ, Babb PJ: Effect of NHS breast screening programme on mortality from breast cancer in England and Wales, 1990-8: comparison of observed with predicted mortality. BMJ 2000, 321:665-669.

58. Thomson CS, Brewster DH, Dewar JA, Twelves CJ: Improvements in survival for women with breast cancer in Scotland between 1987 and 1993: impact of earlier diagnosis and changes in treatment. Eur J Cancer 2004, 40:743-753.

59. Jørgensen KJ, Zahl PH, Gøtzsche PC: Breast cancer mortality in organised mammography screening in Denmark: comparative study. BMJ 2010, 340:c1241.

Pre-publication history

The pre-publication history for this paper can be accessed here: http://www.biomedcentral.com/1741-7015/10/163/prepub

doi:10.1186/1741-7015-10-163

Cite this article as: Autier and Boniol: Breast cancer screening: evidence of benefit depends on the method used. BMC Medicine 2012 10:163.

\section{Submit your next manuscript to BioMed Central and take full advantage of:}

- Convenient online submission

- Thorough peer review

- No space constraints or color figure charges

- Immediate publication on acceptance

- Inclusion in PubMed, CAS, Scopus and Google Scholar

- Research which is freely available for redistribution

Submit your manuscript at www.biomedcentral.com/submit 